\title{
Hobbes on the Making and Unmaking of Citizens
}

\author{
Dr Maximilian Jaede \\ School of International Relations \\ University of St Andrews \\ Arts Faculty Building, The Scores \\ St Andrews, KY16 9AX \\ United Kingdom \\ mj327@st-andrews.ac.uk
}

This is a pre-proof version of a paper forthcoming in the Critical Review of International Social and Political Philosophy (2016)

\section{Introduction}

Hobbes, in spite of being in favour of absolute and legally unconstrained sovereignty, does not advocate despotic government; rather, he seems to endorse rule by law (Goldsmith 1996, p. 283). Hobbes defines civil laws as commands of the sovereign, who thus sets binding standards for human conduct.

However, scholars differ as to whether or not all of the sovereign's commands qualify as laws. David Dyzenhaus (2001, p. 464) holds that the Hobbesian 'sovereign is by definition one who governs through law', therefore concluding that all absolute rulers are legally constrained insofar as they need to sustain the proper functioning of the legal order. ${ }^{1}$ Thomas Poole (2012) agrees that there are certain restrictions, such as the law's publicity requirement, if sovereigns wish to rule by law. Yet, unlike Dyzenhaus, Poole (2012, p. 85) argues that Hobbes's 'sovereign has a choice between exercising power in two ways, the legal and the extra-legal'.

As for the question of why sovereigns would choose rule by law over despotic government, Poole $(2012$, p. 89) suggests that reason dictates that they do so. A functioning legal order does not only benefit society as a whole. It also appears to be in the sovereign's self-interest, as (an overuse of) extra-legal measures would risk the subjects' trust and might even provoke hostile reactions. ${ }^{2}$ Despite this danger, Poole 
(2012, p. 89) maintains that, in Hobbes's view, overwhelming and unconstrained force is actually 'needed to institute law'. 3

These considerations help to bring out the distinctive features of rule by law within the broader context of Hobbes's political thought. However, Poole seems to attach too much importance to a few acrimonious remarks in Behemoth (Hobbes's late history of the English Civil War), therefore missing out on the intricacies of his argument on the treatment of rebellious citizens. This article additionally examines passages in De Cive and Leviathan, specifically Hobbes's claim in these works that those who defy the sovereign could be treated as public enemies. This analysis leads to the conclusion that the Hobbesian sovereign has the power to decide whether individuals be admitted as legal subjects, or excluded as enemies of the state.

While Hobbes's specific understanding of legal citizenship may be inapplicable today, it will be suggested that he helpfully elucidates broader issues relating to the making and unmaking of citizens. Hobbes argues that subjection to the law can only be sustained if it is accompanied by civic education. Apparently for this reason, he also emphasises that governments need to assume responsibility if citizens engage in hostilities against their state. This, it will be argued, has important implications for evaluating attempts to deprive individuals of their citizenship. By way of example, the article considers the case of British citizens who joined Islamist militants in the Middle East and could be banned from returning to the United Kingdom.

\section{Sovereign prerogative and the decisive use of force}

In Hobbes's lifetime, the sovereign prerogative was at the heart of constitutional disputes about excessive royal power (Poole 2012, p. 69). This is reflected in Hobbes's late work Behemoth (1990), which presents an account of the events leading to the English Civil War. In this context, Hobbes (1990, p. 26) explicitly addresses the prac- 
tice of Parliament 'call[ing] in question [the monarch's] prerogative by petitions of right and other devices', which eventually provoked civil war.

Hobbes (1990, p. v), in his attempt to explain these events, emphasises the role of 'certain opinions in divinity and politics'. In particular, he suggests that Presbyterian teachings and classical notions of democracy inspired people to defy the sovereign authority (Hobbes 1990, pp. 2-3). Yet, as Poole (2012, p. 71) aptly observes, the spread and implementation of such 'seditious' doctrines was only made possible by the monarch's lack of decisiveness in dealing with these challenges. When Parliament passed a bill of attainder to execute one of the monarch's close advisors as a traitor, King Charles decided not to intervene (Hobbes 1990, pp. 69-71).

Hobbes further describes how, after this key event, parliamentary motions increasingly undermined the sovereign authority. Thus, it may not be surprising that Hobbes also indicates his preference of drastic measures. He invokes the myth of Hercules' fight with Hydra (i.e. the beast which grew two more heads for every one cut off) to raise the question of whether the King could have acted more decisively (Hobbes 1990, p. 72). In response, he proposes a rather crude reinterpretation: 'Hercules at first did not cut off those heads, but bought them off; and afterwards, when he saw it did him no good, then he cut them off, and got the victory' (Hobbes 1990, p. 72). This seems to suggest that Charles, instead of negotiating with Parliament, should have suppressed their opposition through the decisive use of force.

Additionally, Hobbes (1990) offers some ideas as to how the King should have used his prerogative to prevent the spread of 'seditious' doctrines. After suggesting that Presbyterian teachings were one of the primary causes of the Civil War, which killed nearly 100,000 people, he advances this argument: 
Had it not been much better that those seditious ministers, which were not perhaps 1000 , had been killed before they had preached? It had been (I confess) a great massacre; but the killing of 100.000 is a greater. (Hobbes 1990, p. 95).

As Poole (2012, p. 74) notes, this may imply that extra-legal killings of ministers could have prevented the breakdown of public order. Yet it needs to be said that Hobbes's sardonic proposal comes after an excursus on religious authority in ancient times. He mentions that Ethiopian priests even ordered their kings to commit suicide. This only stopped when one monarch 'killed all the priests, abolished the custom, and rectified the kingdom according to his will' (Hobbes 1990, p. 94).

In contrast to this story, Hobbes's account of the actual events prior to the Civil War indicates that sovereigns cannot simply apply unconstrained force against their own citizens. The King's attempt to prosecute Members of Parliament was met with considerable resistance, and, as Hobbes (1990, pp. 96-98) describes, only resulted in further parliamentary motions to limit the royal prerogative.

If there are any conclusions to be drawn from Behemoth, it is that such drastic measures carry a great risk for the sovereign, whose power ultimately depends on the citizens' obedience (Hobbes 1990, p. 27). Thus, Hobbes notes that, although the King had a right to command all forces of the state, 'all the trained soldiers, and in a manner all his subjects, were by the preaching of Presbyterian ministers, and the seditious whisperings of false and ignorant politicians, made his enemies' (Hobbes 1990, pp. 27-28). What is more, Hobbes points out that

\footnotetext{
the English would never have taken well that the Parliament should make war upon the King, upon any provocation, unless it were in their own defence, in case the King should first make war upon them; and, therefore, it behoved them to provoke the King, that he might do something that might look like hostility. (Hobbes 1990, p. 28).
}

In other words, the King's poor attempt to use of force against Members of Parliament only played into the hands of those who sought to deprive him of his power, and was perhaps even provoked by them in order to justify a rebellion. 
This casts doubt on the suggestion that Hobbes advocates the use of unconstrained force against rebellious citizens. As will be shown in the next section, his position is actually more sophisticated than that. In De Cive and Leviathan, which are not closely examined by Poole (2012), ${ }^{4}$ Hobbes addresses questions concerning the sovereign's right of war, the crime of treason, and the legal status of rebels in order to establish upon what grounds rulers may use force against them.

\section{The legal status of rebels and their punishment}

Given that Hobbes defines civil laws as commands of the sovereign, it follows that rule by law presupposes subjection. Presumably, this makes it difficult to apply the law in the event of rebellion (with the latter being understood as defiance of sovereign authority). As Hobbes (1997, p. 166) argues in De Cive, 'unless the citizens are previously obligated to obedience, i.e. not to rebel, every law is invalid'.

A law in the form 'do not rebel!' may also be superfluous, because, as Hobbes (1997, p. 166) further points out, citizens are already obliged to obey their sovereign on the ground of natural law. Consequently, Hobbes also invokes the latter to establish a basis for punishing rebellious citizens. ${ }^{5}$ He suggests that rebels and traitors are punished 'by natural right, i.e. not as bad citizens, but as enemies of the commonwealth' (Hobbes 1997, p. 166). The sovereign retains, as Hobbes (1997, p. 77) further elaborates, his original right of war against dissenters. ${ }^{6}$ In addition, Hobbes draws a comparison between rebels and those who defy God's authority:

[T] he atheist is punished directly by God or by kings appointed by God, not as a subject is punished by a king on the ground that he has not kept the laws, but as an enemy is punished by an enemy because he has refused to accept the laws. (Hobbes 1997, p. 164).

In response to objections to this claim, Hobbes (1997, p. 164) explains in an annotation that he sought to establish a legal basis for punishing atheists. Supposedly in the absence of suitable civil law prohibitions, he invoked natural law. 
In Leviathan, Hobbes (2012) advances similar views on the punishment of rebels. His definition of punishment as harm inflicted by public authority with the intention to better dispose citizens to obedience (Hobbes 2012, p. 482) seems to imply that legal penalties presuppose subjection to the sovereign. Indeed, Hobbes $(2012$, p. 522) points out that people who are unaware of their obligation to obey their ruler would interpret any punishment 'as an act of Hostility; which when they think they have strength enough, they will endeavour by acts of Hostility, to avoyd'. Hobbes (2012, pp. 484-486) generally distinguishes between legal penalties and 'acts of hostility', including evils not inflicted by public authority and punishment without prior law, which do not meet the requirements of his definition of punishment.

Moreover, Hobbes points out that harm inflicted on declared enemies should not be called punishment, '[b]ecause seeing they were either never subject to the Law, and therefore cannot transgresse it; or having been subject to it, and professing to be no longer so, by consequence deny they can transgresse it' (Hobbes 2012, p. 486). ${ }^{7}$ Yet, regardless of how those who defy the sovereign authority interpret their own treatment, they will, of course, be punished for their offences:

[I]n denying subjection [the rebel] denyes such Punishment as by the Law hath been ordained; and therefore suffers as an enemy of the Common-wealth; that is, according to the will of the Representative. For the Punishments set down in the Law, are to Subjects, not to Enemies; such as are they, that having been by their own act Subjects, deliberately revolting, deny the Sovereign Power. (Hobbes 2012, p. 486).

As a consequence of their defiance of the sovereign authority, rebels suffer at the sovereign's will. In other words, they do not receive the penalties that the law ordains for certain offences, but have to expect arbitrary punishment. This reading finds further support in Hobbes's (1840, p. 291) response to Bishop Bramhall, one of his main intellectual opponents: '[T]he traitor loseth the privilege of being punished by a prece- 
dent law; and therefore may be punished at the king's will'. Thus, Hobbes denies that the treatment of rebels must fulfil the criteria of legal penalties.

Hobbes's argument that the sovereign could use his right of war to inflict arbitrary punishment on traitors appears to be based on a particular conception of their status as enemies. In this regard, it is illuminating that, both in the original text of $D e$ Cive and the Latin version of Leviathan, Hobbes consistently refers to rebels and traitors as hostes (public enemies) rather than inimici (private enemies). ${ }^{8}$

This seems to imply that their hostility towards the sovereign also affects their legal status as citizens. In the Dialogue of the Common Laws, Hobbes explicitly rejects an alternative position expressed by Sir Edward Coke (2003, p. 973). Coke had argued that traitors are not hostes but inimici (i.e. private enemies within the confines of the law). Hobbes $(2005$, p. 72) finds Coke's argument 'not [...] worthy of the meanest lawyer', and considers it manifest that traitors are public enemies: '[F]or the Nature of Treason by Rebellion; is it not a return to Hostility?' (Hobbes 2005, p. 73). The notion of a 'return' of hostility, thereby, seems to allude to his concept of the state of nature, in which everybody was originally at war with everybody else. ${ }^{9}$

Indeed, Hobbes defends the view that, as public enemies, rebels would return to the natural condition of war. He considers the possibility of banishment from the commonwealth for the first time in The Elements of Law, suggesting that 'exile perpetual, is a release from subjection, forasmuch as being out of the protection of the sovereignty that expelled him, [a banished man] hath no means of subsisting but from himself' (Hobbes 1994, p. 125). Such a return to the state of nature would presumably imply that individuals retain their full natural right, including the blameless liberty to use force against others. Yet Hobbes (1997, p. 105) also states in De Cive that, in the case of banishment, 'freedom is given as a punishment'. This clearly shows that, for 
Hobbes, returning to the state of nature (where people have a right to all things necessary for self-preservation) is all but desirable.

In Leviathan, Hobbes (2012, p. 492) affirmatively cites Cicero's conception of exile and argues that a banished person is an enemy of the state. ${ }^{10}$ Thereby, Hobbes apparently distinguishes between exiles that are allowed to live in another country, which would not in itself constitute punishment, and those excluded from all political associations. As he argues in his so-called 'reply to the fool', someone who denies the obligation to keep covenants cannot be tolerated in any commonwealth, and if this person is 'left, or cast out of Society, he perisheth' (Hobbes 2012, p. 224). Similarly, Hobbes (2012, p. 232) states, in his discussion of the natural law of complaisance, that people who cannot be corrected ought to be 'cast out of Society'.

The analysis so far suggests that Hobbes invokes the sovereign's right of war and the legal status of rebels as public enemies in order to resolve a problem of law enforcement. Those who defy the sovereign authority can, in his view, not be punished on the basis of civil law (which presupposes subjection). However, the sovereign may banish them, or inflict arbitrary harm, which might serve as a functional equivalent to legal penalties. In particular, it seems that such punishment of rebels could deter other members of society from defying the sovereign authority.

Yet while Hobbes in effect proposes extra-legal penalties, he seeks to establish that rebellious citizens 'may lawfully be made to suffer whatsoever the Representative will' (Hobbes 2012, p. 486, emphasis added). Hence, he apparently finds it important to establish that such a treatment of rebels is in accordance with the natural laws. Hobbes also does not seem to envision a general suspension of civil law. Rather, it appears that the latter is merely no longer applied to particular individuals, who are excluded from ordinary jurisdiction after revealing their hostility. This does not nec- 
essarily affect the status of other citizens, who might still enjoy legal certainty as long as they do not commit the same offence (i.e., defy the sovereign).

What is more, rebels need to be convicted of treason before they may be treated as public enemies, which could be achieved through judicial procedure. Far from advocating secret killings, as Poole (2012, p. 80) suggests, Hobbes seems to uphold the principle of publicity, therefore being particularly concerned with establishing what evidence would be sufficient for conviction. In De Cive, he defines the crime of lèsemajesté (high treason) as 'a deed or word by the citizen or subject by which he reveals that he no longer intends to obey the [sovereign]' (Hobbes 1997, p. 165). As becomes apparent from the following discussion, Hobbes (1997, p. 165) explicitly seeks to include public utterances that seek to justify disobedience in this category. ${ }^{11}$ In Leviathan, he similarly states that high treason covers 'all endeavours by word, or deed to diminish the [sovereign] Authority' (Hobbes 2012, p. 478).

Hobbes further elaborates his position in the Dialogue of the Common Laws, thereby disagreeing with Coke on two key points. Firstly, Hobbes (2005, p. 224) maintains that "not only the killing [of the monarch], but the Design is made High Treason [by the law]". This would imply that, in general, a hostile design that is not yet put into practice is sufficient for convicting a rebel. Secondly, Hobbes seeks to establish that there is no need for proof by an open deed:

$[\mathrm{H}]$ ow a Jury from providing, or buying of Armour, or buying of Gunpowder, or from any other overt Act, not Treason in itself, can infer a Design of Murdering the King, unless there appear some words also, signifying to what end he made such Provision, I cannot easily conceive. (Hobbes 2005, p. 76).

This leaves Hobbes (2005, pp. 76-77) with the position that utterances are the best possible proof, which he defends against Coke's proposition that 'bare words' may be sufficient evidence for the crime of heresy, yet not for high treason. ${ }^{12}$ 
Hobbes $(2005$, p. 75$)$ points out that, strictly speaking, the law 'maketh not the words High Treason, but the Intention, whereof the words are but a Testimony'. Yet in effect, he argues that rulers could apply their right of war against citizens who reveal their hostility through utterances defying the sovereign authority. While this argument may lack subtlety, it shows that, in order to combat 'seditious' speeches, Hobbes does not simply advocate extra-legal (or even secret) executions; rather, he attempts to provide a legal basis for punishing rebellious citizens.

\section{The distinction between citizens and public enemies}

Hobbes's argument concerning the punishment of rebels provides an insight into his conception of the legal status of citizens (or subjects), ${ }^{13}$ who can, as has been shown, be lawfully excluded from society by the sovereign. This section will further examine Hobbes's distinction between enemies and subjects, arguing that legal citizenship generally depends on the sovereign's right of war and peace.

As is well known, Hobbes's social contract theory conceives of the state's constitution in terms of a transfer of right. The commonwealth comes into being when people renounce their natural right to all things, and thus 'conferre all their power and strength upon one Man, or upon one Assembly of men, that may reduce all their Wills [...] unto one Will' (Hobbes 2012, p. 260). Based on this idea, Hobbes (2012, p. 262) concludes that 'sovereign' is the person (or assembly) who gains absolute authority, while every other member of society becomes a 'subject'. Thus, citizens of a Hobbesian commonwealth are defined in terms of their subjection to the sovereign.

In other passages, Hobbes contrasts the status of citizens vis-à-vis that of public enemies. As he claims in De Cive, 'everyone is an enemy [hostis] to everyone whom he neither obeys nor commands' (Hobbes 1997, p. 108). Similarly, when arguing that atheists should be treated as God's enemies, he points out that 'men are enemies 
[hostes] to each other when they are not subject one to another or to any common ruler' (Hobbes 1997, p. 164). In Leviathan, Hobbes (2012, p. 494) states: ‘[A]1l men that are not Subjects [Cives], are either Enemies [hostes], or else they have ceased from being so, by some precedent covenants'. Yet, as is suggested by the equivalent passage in the Latin Leviathan, the option of being neither subject nor enemy is only available to states, which could become allies (Hobbes 2012, p. 495). Hence, his view is that individuals must either be enemies or members of the state.

This raises questions about whether it is truly up to individuals to decide whether to enter or to leave the commonwealth. ${ }^{14}$ It certainly follows from Hobbes's social contract theory that the obligation to obey the sovereign arises from a transfer of right. Obligation may also stem from tacit or attributed consent, including the mere fact of people living under the sovereign's protection (Hoekstra 2004, pp. 67-69). However, while express or tacit consent have important implications as the basis for the citizens' obligation to obedience, consent alone appears to be insufficient to determine their status before the law. The latter, as has been suggested in the last section, also depends on the judgement of the sovereign, who possesses the right to determine whether or not someone should be excluded from the commonwealth.

While Hobbes defines civil laws as commands of the sovereign, he generally allows for the possibility that elements of the legal order derive from presumptions about the sovereign's will (Dyzenhaus 2001, p. 482). For instance, Hobbes (2012, p. 420) insists that the authority of customary law solely depends on the present sovereign. Presumably all laws remain in force until a ruler declares the opposite, because 'none can abrogate a Law made, but the Soveraign' (Hobbes 2012, p. 416). Moreover, it seems that the Hobbesian sovereign, who has absolute and undivided authority, tacitly sanctions everything that is not prohibited by the law. Thus, Hobbes (2012, p. 
340) argues that 'where the Soveraign has prescribed no rule, there the Subject hath the Liberty to do, or forbeare, according to his own discretion'.

Given that Hobbes attributes great significance to such inferences, it seems plausible that members of society are legal subjects unless the sovereign explicitly declares the opposite. Analogous to the case of sovereignty by acquisition, where a ruler explicitly admits members of a vanquished state as citizens (Hobbes 2012, p. 312), sovereigns may be said to tacitly sanction the status of all members of society. Other statements in Leviathan also suggest that subjection thus depends on the sovereign's will. In his discussion of the natural law of pardon, Hobbes (2012, p. 232) describes the admission of previously hostile individuals as a 'granting of Peace' upon the condition that these people do not 'persevere in their hostility'. Furthermore, Hobbes (2012, p. 312) considers the liberties of servants (in contrast to the confinement of slaves) as evidence of the trust which their ruler has invested in them.

The legal basis for admitting or excluding citizens, thereby, appears to be the ruler's right of war and peace, which Hobbes (1997, pp. 79, 88; 2012, pp. 306, 342, 448) includes among the essential powers of sovereign authority. As a passage from $D e$ Cive shows, this right does not only concern making war and peace with other states, it also permits the making and unmaking of citizens:

$[\mathrm{N}]$ o citizen may privately determine who is an ally [amicus] or public enemy [hostis publicus] of the commonwealth, nor when to make war or alliance, peace or truce; nor may he decide what is for or against the interest of the commonwealth in the matter of who are to be citizens [cives], and who should have what authority, nor what doctrines, morals, and public pronouncements are useful, and what unions of which men. (Hobbes 1997, p. 214).

Thus, the sovereign's absolute authority extends to the question of 'who are to be citizens', which presumably refers to the admitting (and excluding) of citizens. ${ }^{15}$ This seems plausible insofar as the authority of Hobbesian sovereigns does not depend on the consent of particular individuals, but on that of a multitude. 
Although the discussion of the sovereign's exclusive rights in Leviathan is less clear on this point, it lends itself to a similar conclusion:

[I]t belongeth of Right, to [the sovereign] to be Judge both of the means of Peace and Defence; and also of the hindrances and disturbances of the same; and to whatsoever he shall think necessary to be done, both before hand, for the preserving of Peace and Security, by prevention of Discord at home, and Hostility from abroad; and, when Peace and Security are lost, for the recovery of the same. (Hobbes 2012, p. 270).

Hobbes's reference to 'hindrances' and 'disturbances' may signify the sovereign's right to decide who is a public enemy. Moreover, he clearly expresses in the above passage that a ruler is allowed to do everything necessary for preventing war and restoring peace. This may be an allusion to the prerogative of pardon, which Hobbes, as mentioned above, defines as a granting of peace. Elsewhere in Leviathan, he points out that all offences against the state (including acts of treason) 'may without breach of Equity be pardoned' by the sovereign (Hobbes 2012, p. 534). ${ }^{16}$ As will be argued in the next section, Hobbes also seems to conceive of the prerogative of pardon as an instrument for restoring public order during an insurgence.

In the Dialogue of the Common Laws, Hobbes (2005) further develops his views on the prerogative of pardon in opposition to Sir Edward Coke's doctrine. Rejecting Coke's claim 'that for the peace of the Land, it would help, that no pardon were granted but by Parliament', Hobbes (2005, p. 127) considers pardoning an essential right of sovereign authority. He suggests that this power, which cannot be subject to any legal restrictions, is based on the sovereign's exclusive right 'to judge of what is good and evil to the Common-wealth' (Hobbes 2005, p. 129).

While the sovereign gains absolute authority through the social contract, his right of war and peace appears to be retained from the natural condition. Hobbes (2012, p. 482) states in Leviathan that citizens have not literally transferred rights to the sovereign, 'but onley in laying down [their rights], strengthened him to use his own, as he 
should think fit, for the preservation of them all'. Hence, the sovereign alone retains his natural right, which permits everything required for self-preservation, including the 'subduing, hurting, or killing [of] any man' (Hobbes 2012, p. 482). This seems to suggest that the right of war and peace is contained in the sovereign's natural right, which is prior to the constitution of the state. Indeed, Hobbes (1997, p. 69) sometimes identifies the natural right with the right of war.

In view of the distinction between enemies and citizens, the fact that the right of war and peace is retained from the state of nature appears to be of crucial importance. Given that civil law presupposes subjection to the legislator, the legal order of the Hobbesian state must depend on the sovereign's exclusive right of war and peace. Without the latter, individuals could not be constituted as citizens (and thus distinguished from public enemies). If this reading is accepted, it follows that the sovereign prerogative is not simply, as Poole (2012) suggests, a precondition for the effective exercise of legal authority. It is a precondition of rule by law as such.

\section{How sovereigns should use their prerogative}

After examining Hobbes's views on the right of war and peace, along with the legal distinction between citizens and public enemies, it is now possible to reconsider the question of how sovereigns should use their prerogative. Hobbes, as will be demonstrated in this section, seems to be of the opinion that the right of war and peace can be employed to restore public order in the face of rebellion.

In general, Hobbes seems to commend a penal policy with a focus on deterring ambitious citizens from inciting a rebellion (Baumgold 1988, p. 113). Thus, he points out in De Cive that punishments should, above all, seek to discourage the formation of factions and opposition to the current government (Hobbes 1997, p. 148). In Leviathan, Hobbes (2012, p. 542) argues, in a similar vein, that 'the severest Punishments 
are to be inflicted for those Crimes, that are of most Danger to the Publique, such as those which proceed from malice to the Government established'. As has been demonstrated above, the sovereign may, according to Hobbes, even revert back to using the right of war for the purpose of punishing rebellious citizens.

Yet Hobbes is not merely concerned with penalties for particular individuals, but seems to suggest that the sovereign should exercise his right of war in conjunction with the prerogative of pardon. As Thomas Schrock (2006, p. 106) observes, he apparently proposes a strategy of 'divide and conquer — the sovereign divides the rebellious collectivity facing him by offering pardons to some of the rebels'. This reading finds some support in the following passage from Leviathan:

[In the punishment of] Crimes of Infirmity; such as are those which proceed from great provocation, from great fear, great need, or from ignorance whether the Fact be a great Crime, or not, there is place many times for Lenity, without prejudice to the Common-wealth; and Lenity when there is such place for it, is required by the Law of Nature. The Punishment of the Leaders, and teachers in a Commotion; not the poore seduced People [...] can profit the Common-wealth by their example. (Hobbes 2012, p. 544).

While those who incite others to take up arms against the sovereign should thus be severely punished, this is not the case for 'poor seduced people'. Hobbes clearly considers it more reasonable to show mercy towards the latter.

Hobbes was certainly aware of amnesties issued after a rebellion or civil war. ${ }^{17}$ However, as Schrock (2006) suggests, pardon may also be considered as an instrument for breaking up an ongoing rebellion. The stratagem of 'divide and conquer' is, thereby, obviously not an original idea of Hobbes. It also features, for example, in one of the most well known histories of a rebellion, i.e. Sallust's Catiline's War. ${ }^{18}$ The Roman historian describes how the Senate 'pronounced Catiline and [his coconspirator] Manlius enemies and appointed a day before which the rest of their crowd [...] could put down their arms with impunity' (Sallust 2007, p. 24). 
In Leviathan, Hobbes (2012, p. 340) seems to consider the possibility of using the right of war and peace in a similar way. He first notes that group resistance against the state is generally unlawful. Despite this, it would be permissible to form a defensive league if a number of citizens had already unjustly resisted the sovereign, or all expected a death sentence (Hobbes 2012, p. 340). Yet the subsequent condition indicates that Hobbes, perhaps, only grants such an extensive right to show how it could be inhibited by sovereign prerogative: 'But the offer of pardon taketh from them, to whom it is offered, the plea of self-defence, and maketh the perseverance in assisting, or defending the rest, unlawful' (Hobbes 2012, p. 340). Although he does not explicitly state that sovereigns should use pardon to thus subvert group resistance, it may be inferred that this is how the sovereign prerogative could be effectively exercised in order to break up an insurgence. As Hobbes notes in De Cive, uprisings generally depend on effective leadership (Hobbes 1997, pp. 138-139). Hence, a sovereign may be well advised to single out those who lead and instigate the rebellion, while at the same time trying to win back the allegiance of other participants.

Schrock (2007, p. 106) is unconvinced by such a strategy: 'Can the Hobbesian sovereign sink so low? - to peddling pardons?' Yet this objection misses the importance that Hobbes generally attributes to the prerogative of pardon, which he likens to a granting of peace. As has been shown, granting peace may be regarded as constitutive of the status of citizens, and by extension of the entire legal system (insofar as the latter presupposes subjection to the sovereign who 'commands' the law). If viewed in this light, it is understandable why Hobbes apparently advocates the discriminatory use of the sovereign's right of war and peace for the purpose of restoring public order. Not being achievable through the use of force alone, this ultimately re- 
quires that some individuals who engaged in hostilities against the state, and especially the 'poor seduced people', be readmitted as legal subjects.

Furthermore, it is important to note that the dissimilar treatment of insurgents implies an acknowledgement of responsibility. At first sight, Hobbes seems to exclusively blame rebel leaders. Yet he also states, in Leviathan, that ' $[\mathrm{t}] \mathrm{o}$ be severe to the People, is to punish their ignorance, which may in great part be imputed to the Soveraign, whose fault it was, they were no better instructed' (Hobbes 2012, p. 544). Hence, it seems that, in granting peace to those incited to rebellion, the sovereign accepts responsibility for their apparent ignorance of the grounds of political obligation (i.e., the precepts of natural law that dictate obedience to an absolute ruler). Making sure that these principles are publicly taught is, as Hobbes (2012, p. 520) insists in the same chapter, one of the sovereign's most fundamental duties.

Hobbes's views on the exercise of sovereign authority in the face of rebellion may be construed as an answer to the question of how rulers could make war upon their own citizens without provoking further hostilities. However, while Hobbes's specific concern is with the treatment of rebellious citizens, his arguments seem to have more general implications. In particular, sovereigns have a responsibility to educate individuals in order make them better suited for subjection to the law.

\section{Conclusion}

Hobbes advocates absolute and legally unconstrained sovereign authority, yet he also holds that the state's power and survival is ultimately based on the citizens' consent. If rulers did everything they are allowed to, they would likely undermine their own position and provoke the people's hostility. Therefore, one could conclude that it is in the sovereign's self-interest to avoid despotic rule, maintain the integrity of the legal order, and treat citizens differently from public enemies. 
The distinction between citizens and enemies, thereby, appears to be fundamental for Hobbes's conception of rule by law. While the latter implies a self-limitation of government, it also presupposes subjection to the sovereign who acts as the sole legislator and supreme judge. Hobbes invokes the sovereign's exclusive right of war in order to provide a basis for the punishment of rebels. However, as has been demonstrated, he also seems to hold that sovereign authority generally extends to the question of whether individuals be admitted as legal subjects; those who defy the sovereign authority could, alternatively, be treated as public enemies. Hence, somewhat paradoxically, Hobbesian rule by law appears to be grounded in a notion of legal citizenship as being subject to a legally unconstrained sovereign.

On this basis, Hobbes commends the exemplary punishment of rebel leaders in order to deter disobedience. Yet what seems even more important is that those who were incited to participate in an insurgence be readmitted as citizens. Sovereigns could, as has been suggested, use their prerogative of pardon for the purpose of restoring public order. Granting peace to most of the rebels might not only be politically expedient; it also implies acceptance of responsibility for the uprising. According to Hobbes, rebellion partly results from the sovereign's failure to instruct the people in the grounds of their obligation to obey the law. Thus, in order to be sustainable, subjection to the law needs to be complemented by civic education. ${ }^{19}$

This opens up a broader perspective on attempts to deprive terrorist or insurgents of their citizen rights. The British Government, for example, has recently considered banning nationals who joined Islamist militants in Syria and Iraq from returning to their home country. In response to such plans, the government's Independent Reviewer of Terrorism Legislation proposed to instead consider the situation 'in terms of young, possibly vulnerable people caught up with the wrong crowd in Syria-didn't 
really know exactly what they were doing' (BBC 2014). This would amount to a Hobbesian attempt to rehabilitate the 'poor seduced people'. Additionally, Hobbes would invite any government to assume responsibility if their citizens turned into enemies of the state. This is because an agency with the power to make and unmake citizens could presumably have averted these people from engaging in hostilities (such as through preventing their ideological radicalisation).

Hobbes's specific understanding of the legal status of citizens certainly differs from a rights-based conception of citizenship, and international law now prohibits the deprivation of nationality in most cases. However, to the extent that modern states continue to have considerable power over the lives of individuals, Hobbes's views help to bring out what is at stake. His ideas on the sovereign's right to exclude citizens, and duty to educate those who have been admitted as members of society, both do not sit easily with his reception as a proto-liberal. ${ }^{20}$ But there may be some truth in Hobbes's suggestion that civic education is required to prevent legal citizens from engaging in hostilities against their own state.

\section{References}

Baumgold, D., 1988. Hobbes's political theory. Cambridge: Cambridge University Press.

BBC, 2014. Concerns over terror exclusion plans [online]. Available from: http://www.bbc.co.uk/news/uk-politics-30206231 [Accessed 4 December 2014].

Cicero, M.T., 1856 [69 BC]. The orations of Marcus Tullius Cicero, vol. 2. Ed. and trans. C.D. Yonge. London: George Bell \& Sons.

Coke, E., 2003 [1644]. The selected writings and speeches of Sir Edward Coke, vol. 2. Ed. S. Sheppard. Indianapolis, IN: Liberty Fund.

Dietz, M.G., 1990. Hobbes's subject as citizen. In: M.G. Dietz, ed. Thomas Hobbes and political theory. Lawrence, KS: University of Kansas Press, 91-119.

Dyzenhaus, D., 2001. Hobbes and the legitimacy of law. Law and philosophy, 20 (5), 461-498.

Flathman, R.E., 2002. Thomas Hobbes: scepticism, individuality, and chastened politics, new edition. Lanham, MD: Rowman \& Littlefield.

Goldsmith, M.M., 1996. Hobbes on law. In: T. Sorell, ed., The Cambridge Companion to Hobbes. Cambridge: Cambridge University Press, 274-305. 
Hobbes, T., 1994 [1640]. The elements of law, natural and politic. Ed. J.C.A. Gaskin. Oxford: Oxford University Press.

Hobbes, T., 1983 [1642/1647]. De Cive: the Latin version. Ed. H. Warrender. Oxford: Clarendon Press.

Hobbes, T., 1997 [1642/1647]. On the citizen. Ed. and trans. R. Tuck and M. Silverthorne. Cambridge: Cambridge University Press.

Hobbes, T., 2012 [1651]. Leviathan, vol. 2. Ed. N. Malcolm. Oxford: Clarendon Press.

Hobbes, T., 2005 [1666]. Writings on common law and hereditary right. Ed. A. Cromartie and Q. Skinner. Oxford: Clarendon Press.

Hobbes, T., 1840 [1668]. The English works of Thomas Hobbes of Malmesbury, vol. 4. Ed. W. Molesworth. London: Bohn.

Hobbes, T., 1990 [1681]. Behemoth, or the long parliament. Ed. F. Tönnies. Chicago: The University of Chicago Press.

Hoekstra, K., 1997. Hobbes and the foole. Political theory 25 (5), 620-650.

Hoekstra, K., 2004. The de facto turn in Hobbes's political philosophy. In: T. Sorell and L. Foisneau, eds. Leviathan after 350 years. Oxford: Clarendon Press, 33-73.

Holmes, S., 2010. Does Hobbes have a concept of the enemy? Critical Review of International Social and Political Philosophy, 13 (2-3), 371-389.

Olsthoorn, J. 2014. Forfeiting citizenship: Hobbes on rebels, traitors and enemies. In: P.M. Kitromilides, ed. Athenian legacies: European debates on citizenship. Florence, Italy: Olschki, 237-252.

Poole, T., 2012. Hobbes on law and prerogative. In: D. Dyzenhaus and T. Poole, eds. Hobbes and the law. Cambridge: Cambridge University Press.

Sallust, 2007 [c. 44 BC]. Catiline's war, the Jugurthine war, histories. Ed. and trans. A.J. Woodman. London: Penguin.

Schrock, T.S., 2006. Resistance to punishment: controversies old and new. In: Svetozar Minkov, ed. Enlightening revolutions: essays in honor of Ralph Lerner. Lanham, MD: Lexington, 91-126.

Sorell, T., 2004. The burdensome freedom of sovereigns. In: T. Sorell and L. Foisneau, eds. Leviathan after 350 years. Oxford: Clarendon Press, 183-196.

Sreedhar, S., 2010. Hobbes on resistance: defying the Leviathan. Cambridge: Cambridge University Press.

Waldron, J., 2001. Hobbes and the principle of publicity. Pacific philosophical quarterly 82 (3-4), 447-474.

Zarka, Y.C., 2004. The political subject. In: T. Sorell and L. Foisneau, eds. Leviathan after 350 years. Oxford: Clarendon Press, 197-182.

[7897 words, including abstract, notes, and bibliography]

\section{Notes}

\footnotetext{
${ }^{1}$ Civil laws must not undermine the integrity of the legal order. For instance, Dyzenhaus (2001, p. 478) suggests that the sovereign could not issue a law that allows judges to give judgement to the party that offers the biggest bribe, as this would subvert the office of judicature.

2 This relates to the more general argument that Hobbesian sovereigns have prudential reasons to govern well. See, for example, Baumgold (1988, pp. 101-119) and Sorell (2004). There might, of course, also be additional moral reasons to govern well.
} 
${ }^{3}$ What Poole seems to have in mind is that Hobbes's sovereign is only able to sustain a functioning legal order if he could, under exceptional circumstances, revert back to using the prerogative.

4 Poole $(2012$, p. 86) notes that Hobbes, in his main political works, does not explicitly address questions concerning the prerogative. However, it still seems essential to further analyse Hobbes's statements on the sovereign's rights in the earlier writings. Despite the fact that he does not use the word 'prerogative', Hobbes is essentially concerned with prerogative powers.

${ }^{5}$ Cf. Olsthoorn's (2014, pp. 240-242) analysis of Hobbes's views on the distinctive features of the crime of treason.

${ }^{6}$ The right of war, as will be shown below, is contained in the natural right that the sovereign retains from the state of nature. Subjects renounce their natural right in the social contract.

${ }^{7}$ Note that this apparently constitutes a departure from De Cive, where Hobbes previously described the treatment of rebels as 'punishment'. However, despite the change in terminology, Hobbes still seems to hold in Leviathan that rebels are effectively punished for their offence of defying the sovereign, even if the evil inflicted upon them does not (have to) fulfil the criteria of Hobbes's definition of legal punishment. Stephen Holmes (2010, p. 372) therefore seems to be mistaken when he writes, in regards to Hobbes's statements on the treatment of rebels, that ' $[t]$ he enemy is not a criminal, has broken no laws, and can be killed even though he is in no way guilty of a crime'.

${ }^{8}$ See Hobbes (1983, pp. 83, 137, 201, 215, 217) and Hobbes (2012, pp. 487, 493, 495). To my knowledge, Hobbes never uses the term inimicus when he refers to enemies who are in a state of war. Rather, this word only appears in biblical quotations (where Hobbes adopts inimicus as the Vulgate term) or in references to personal rivals. See, for instance, Hobbes (1983, pp. 124, 179, 224).

${ }^{9}$ Unlike other writers, Hobbes does not limit the application of the term hostis to organised collectives. He consistently refers to individuals in the state of nature as hostes, not inimici (Hobbes 1983, pp. 96, 97, 164; 2012, pp. 213, 225), which supports the argument that actors in this condition have the same legal status as individuals excluded from the commonwealth.

${ }^{10}$ In the quoted passage from the speech Pro Caecina, Cicero (1856, pp. 64-65) writes that exiles effectively lay down their citizenship, and 'if they chose to remain in the city and to submit to the rigour of the law, they would lose their rights of citizenship sooner than they lost their lives'.

${ }^{11}$ In the preface to De Cive, Hobbes (1997, p. 14) also asks his readers not to believe preachers of 'seditious' doctrines, but to regard them as enemies and report their names to the authorities.

${ }^{12}$ Cf. Hoekstra's (1997, p. 634) discussion of Hobbes's disagreement with Coke on this point.

${ }^{13}$ As Yves Charles Zarka (2004, pp. 177-179) notes, Hobbes generally seems to reduce the idea of citizenship to subjection to the sovereign. While Hobbes rarely uses the word 'citizen' in his English works of political philosophy, the Latin term civis appears frequently in De Cive. However, in the Latin version of Leviathan, Hobbes also replaces civis with 'subject'.

${ }^{14}$ Richard Flathman (2002, p. 155), for instance, attributes to Hobbes the view that '[i]t is for me [as an individual] to decide whether to enter and whether to leave political society'.

${ }^{15}$ Susanne Sreedhar (2010, p. 157), who maintains that rebels do not become public enemies, points out that it is difficult to draw 'a sharp line between when someone is a member of civil society and when she is not'. As with all issues that are subject to disagreement, Hobbes seems to hold that it is up to the sovereign to draw the line between members of society and public enemies. This apparent view of Hobbes also explains his occasional use of phrases such as 'rebellious subject', which Sreedhar (2010, p. 157) takes as support for her claim that rebellion is insufficient to terminate the legal status of citizens. Rebellious subjects do not automatically become enemies of the state. However, Hobbes clearly seeks to establish that the sovereign has a right to treat them as such.

${ }^{16}$ In contrast to offences against the state, crimes against private persons can, according to Hobbes (2012, p. 534), only be equitably pardoned with the victims' consent.

${ }^{17}$ In the Dialogue of the Common Laws, Hobbes (2005, pp. 133-134) discusses the oblivion act that was passed after the Interregnum. He also refers to an amnesty in Athens, with which he was probably familiar through his reading of Thucydides' History of the Peloponnesian War.

${ }^{18}$ Citing Sallust, Hobbes (1997, p. 139) refers to Catiline as the archetypical 'author of sedition'. This indicates Hobbes's familiarity with Sallust's history of the rebellion.

${ }^{19}$ Cf. Mary Dietz's (1990) suggestion that the laws of nature can be understood as a (non-republican) doctrine of civic virtue, intended to transform subjects into citizens. In contract to Dietz, who highlights the agency of members of society, the reading advanced here emphasises the sovereign's duty to constitute citizens in order to make them better suited to subjection to the law. 
${ }^{20}$ Flathman (2002, p. 143), who interprets Hobbes as a proto-liberal, notes the awkwardness of objecting to Hobbes's view that the sovereign ought to educate citizens. However, he seems to be right that there are limits to the extent to which sovereigns should attempt to change people's beliefs (Flathman 2002, pp. 146-150). Also see Waldron's (2001) claim that Hobbes does not so much envision ideological indoctrination, but instruction in the truth about politics. 